\title{
Model Predictive Current Control of a Five-level Cascaded H- Bridge Inverter with different Sampling Times
}

\author{
Sundararajan $\mathrm{K}^{1}$, Alamelu Nachiappan ${ }^{2}$, Veerapathiran $\mathrm{G}^{3}$ \\ 1 (Department of Electrical and Electronics Engineering, Sathyabama University, India) \\ 2 (Department of Electrical and Electronics Engineering, Pondicherry Engineering College, India) \\ 3(Department of Electrical and Electronics Engineering, Mailam Engineering College, India)
}

\begin{abstract}
Model predictive current control of a five-level cascaded H-bridge (CHB) inverter with different sampling times is presented in this paper. The purpose of the current controller is to regulate the load current within the set reference current. A simulation model of the five-level CHB inverter with Model Predictive current controller (MPC) has been built to demonstrate the CHB inverter system performance in terms of Total Harmonic Distortion (THD) level of the load current and reference current tracking for a step change with different sampling times. The simulation results are observed by using the MATLAB Simulink software to validate the proposed current control technique.
\end{abstract}

Key Words: Cascaded H-bridge (CHB) multilevel inverter, Model Predictive Current Controller, Total Harmonic Distortion (THD).

\section{Introduction}

In recent trends, multilevel inverters [1], [2], plays an important role in a wide range of industrial applications. The multilevel inverters have several advantages over the traditional converters: operation with voltages over the switching device rating, reduced common-mode voltages, and smaller voltage changes $(d v / d t)$. These inverters can also effectively reduce the switching stress and can provide an output waveform with many voltage levels, which is the main characteristic of these inverters. The application of multilevel converters covers a wide range that includes the following: high-power drives [3], active filters [4], and other industrial applications like conveyor systems, fans, pumps, traction, and ship propulsion. In recent years, an extensive array of multilevel structures has appeared [5]-[11]. They include, the Cascaded H-bridge (CHB), Neutral point clamped (NPC) and Flying capacitor (FC) [12] multilevel structures. The Cascaded H-bridge multilevel inverter is a popular converter topology and has found widespread applications in industry, for instance, in high-power medium-voltage drives [13]-[15] and reactive power compensating [16]. This paper deals with the CHB inverter, which consists of single-phase $\mathrm{H}$-bridge inverters in series connection with independent dc links of equal voltage, to provide the total output voltage to the load [17].

The classical strategies for control and modulation of CHB inverters use linear control and phaseshifted pulse width modulation [18] or space vector modulation [19], [20] modulation in order to generate the switching signals for controlling the converter. Other modulation methods for low switching frequency have also been proposed [21]-[23]. In recent years, new control strategies have been studied for the current control of power inverters. Among them, model predictive control (MPC) has been applied for the control of power converters due to its several advantages, like fast dynamic response, easy inclusion of nonlinearities and constraints of the system, and the flexibility to include other system requirements in the controller [24]-[26]. The MPC uses the load and inverter model in order to predict the future behavior of the system over a horizon in time., but it calculates the variables at the next sample time using all the switching states and selects the one that minimize a given cost function [27]. The cost function represents the desired behavior of the system. Considering that power converters are systems with a finite number of states, given by the possible combinations of the state of the switching devices, the MPC optimization problem can be simplified and reduced to the prediction of the behavior of the system for each possible state. It is flexible and simple to implement, and can be easily applied for the current control in a three-phase inverter [28], [29] and a matrix converter [30], power control in an active front-end rectifier [31], and torque and flux control of an induction machine [32]-[35]. In multilevel converters, MPC has been applied for a three level NPC inverter [36], a flying capacitor converter [37], and an asymmetric 27-level CHB inverter [38] using all the switching states of the system. An MPC approach for selective harmonic elimination is proposed in [39].

In this paper, the MATLAB-simulink model is used to show the performance of the five-level CHB inverter with the proposed current control technique. The performance of the CHB inverter in terms of the load current THD with different sampling times and reference current tracking for a step change with different sampling times. 


\section{Chb Inverter Model}

The CHB inverter model is formed by the series connection of H-bridges with separate DC sources. A three-phase CHB inverter topology is essentially composed of three identical phase legs of the series-chain of H-bridge converters, which can possibly generate different output voltage waveforms and offers the potential for AC system phase-balancing. The AC output voltage is synthesized by the addition of the voltages generated by different $\mathrm{H}$-bridge cells. Each single phase $\mathrm{H}$-bridge generates three voltage levels as $+\mathrm{V}_{\mathrm{dc}}, 0$, $-\mathrm{V}_{\mathrm{dc}}$ by connecting the DC source to the AC output by different combinations of four switches $\left(S_{11}, S_{12}, S_{21}\right.$ and $\left.S_{14}\right)$. For generating five level output voltage, a two-cell CHB three-phase inverter with $R L$ load is modeled as shown in fig (a). The Topology of one cell and the Topology of two cells is shown in fig (b) and (c), respectively.

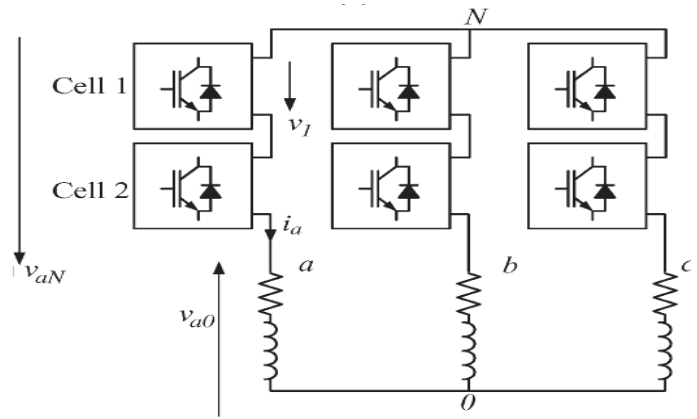

(a)

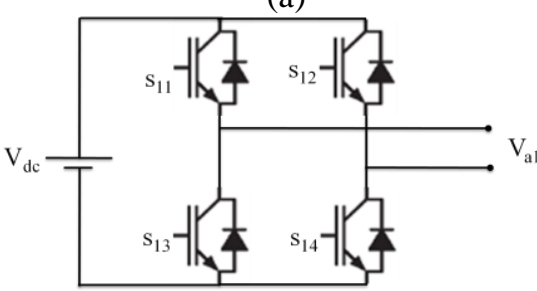

(b)

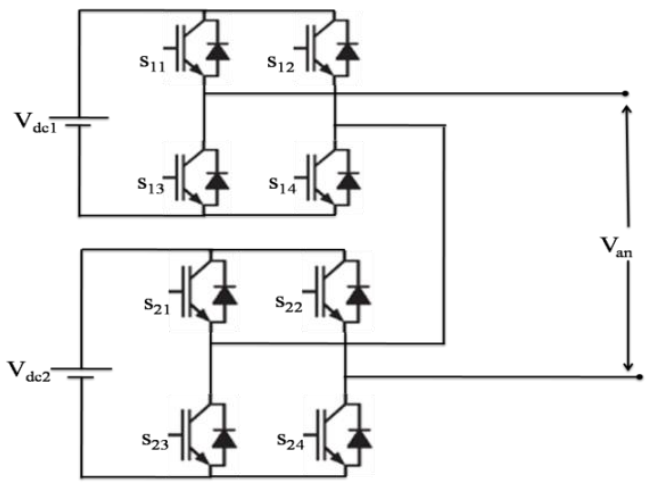

(c)

Fig.1 CHB inverter. (a) Two-cell CHB three-phase inverter with $R L$ load. (b) Topology of one cell. (c) Topology of two cells

For each phase, the number of possible voltage levels is

$m=2 C+1$

Where, $m$ is the number of levels and $C$ is the number of series connected cells in one leg.

In the three-phase CHB inverter, the number of voltage level combinations $K_{m}$ is

$K_{m}=m^{3}$

On the other hand, each cell has two switching signals, and for $C$ cells in each leg, the voltage per leg of the inverter in terms of binary switching signals is

$\mathrm{V}_{\mathrm{aN}}=\mathrm{V}_{\mathrm{dc}} \sum_{\mathrm{j}=1}^{\mathrm{C}}\left(\mathrm{S}_{\mathrm{ij}, 1}-\mathrm{S}_{\mathrm{ij}, 2}\right)$

Where, $S_{i j, 1}$ and $S_{i, 2}$ are the switching signals of the phase $i$ and cell $j$. The possible switching combination $K S$ for a $\mathrm{CHB}$ inverter with $C$ cells in each leg is $K_{S}=2^{6 C}$

From Fig. 1(a), the differential equation for the current of one leg of a three-phase $R L$ load connected to the $\mathrm{CHB}$ inverter is 
$\mathbf{V}_{a n}(t)=L \frac{d i a(t)}{d t}+R i a(t)$

Where, $\mathrm{v}_{a \mathrm{n}}$ is the voltage across the load with reference to its neutral point. However, the voltage across the load in terms of the inverter voltage is

$\mathrm{v}_{a 0}=\mathrm{v}_{a N}+\mathrm{v}_{n 0}$

Where, $\mathrm{v}_{n 0}$ is the common-mode voltage $\left(\mathrm{v}_{c m}\right)$, defined as

$V_{n o}=V_{c m}=\frac{V_{a N}+V_{b N}+V_{c N}}{3}$

The load model can be expressed as a vector equation using the following vectorial transformation:

$\left[\begin{array}{l}\alpha \\ \beta\end{array}\right]=\left[\begin{array}{ccc}\frac{2}{3} & -\frac{1}{3} & -\frac{1}{3} \\ 0 & \frac{\sqrt{3}}{3} & \frac{\sqrt{3}}{3}\end{array}\right]\left[\begin{array}{l}a \\ b \\ c\end{array}\right]$

Where, $a, b$ and $c$ are the three-phase variables of voltage or current, and $\alpha$ and $\beta$ are the vectorial variables. Using this transformation, (5) can be described in terms of the vectorial variables $\alpha-\beta$ as

$\mathrm{V}_{\alpha \beta}(t)=L \frac{d i_{\alpha \beta}(t)}{d t}+R i_{\alpha \beta}(t)$

Where, $\mathrm{V} \alpha, \beta$ is the inverter voltage vector and $\mathrm{i} \alpha, \beta$ is the load current vector.

III. Model Predictive Current Controller

The Model Predictive current control is a conceptually new approach to the nonlinear current control in three-phase inverters. A model of the CHB inverter and the load is used to predict the behavior of the current for each different voltage vector generated by the inverter. The vector that minimizes a quality function is selected. The predictive current control avoids the application of any modulation method in the CHB inverter.

The primary idea of the predictive current control scheme is to predict the behavior of the load current for each possible voltage vector generated by the inverter. The prediction of the current is based on the discretized model of the system [14].

Approximating the derivative $d i / d t$ in (9) by

$\frac{d i_{\alpha, \beta}}{d t} \approx \frac{i_{\alpha, \beta}[k+1]-i_{\alpha, \beta}[k]}{T_{S}}$

and substituting it in (9), the following expression is obtained for the future load current vector:

$\mathrm{i}[k+1] \alpha, \beta=\frac{T_{s}}{L}\left\{V_{\alpha, \beta}[k]-i_{\alpha, \beta}[k]\left(R-\frac{L}{T_{s}}\right)\right\}$

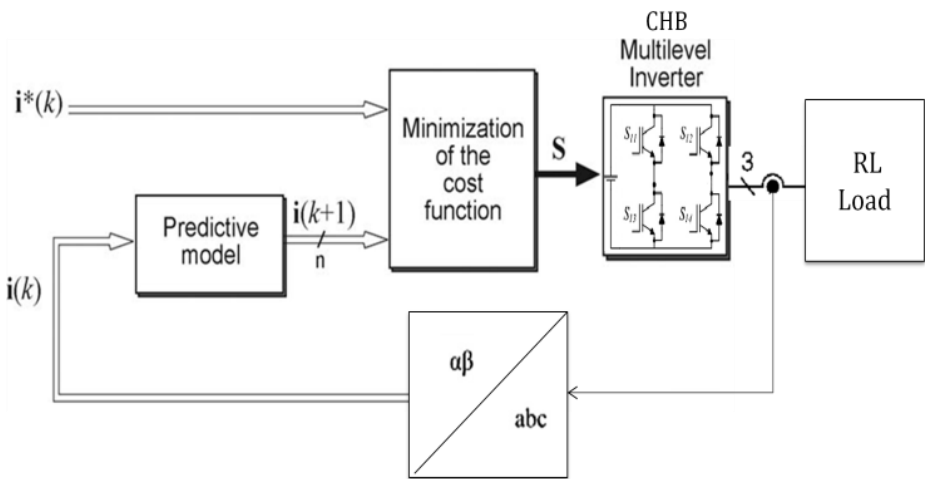

Fig.2. Block diagram of model predictive current controller

The equation (11) will be used in the predictive controller to predict the future value of the load current for a given voltage vector. The current prediction is evaluated by using the following cost function in order to select the appropriate voltage vectors for the current control.

$\mathrm{g}[\mathrm{k}+1]=\left|\mathrm{i}_{\alpha}{ }_{\alpha}[\mathrm{k}+1]-\mathrm{i}_{\alpha}[\mathrm{k}+1]\right|+\left|\mathrm{i}_{\beta}{ }_{\beta}[\mathrm{k}+1]-\mathrm{i}_{\beta}[\mathrm{k}+1]\right|$

where, $\mathbf{i}_{\alpha}{ }_{\alpha}[\mathrm{k}+1]$ is the reference current vector prediction. For sufficiently small sampling times, it can be assumed that $\mathrm{i}_{\alpha, \beta}{ }_{\alpha, \beta}[\mathrm{k}+1] \approx \mathrm{i}_{\alpha, \beta}{ }_{\alpha, \beta}[\mathrm{k}]$. The cost function (12) is evaluated for each possible voltage vector. The voltage vector which minimizes the cost function is selected and applied to the load. The block diagram of the predictive current control is shown in Fig. 6. Here, the measured currents are used for the prediction of the $n$ future values of the load currents, corresponding to the $n$ possible voltage vectors, where $n=125$ for a five-level inverter [40]. These predictions are evaluated by the cost function, and the voltage vector which minimizes this function is selected and applied. 


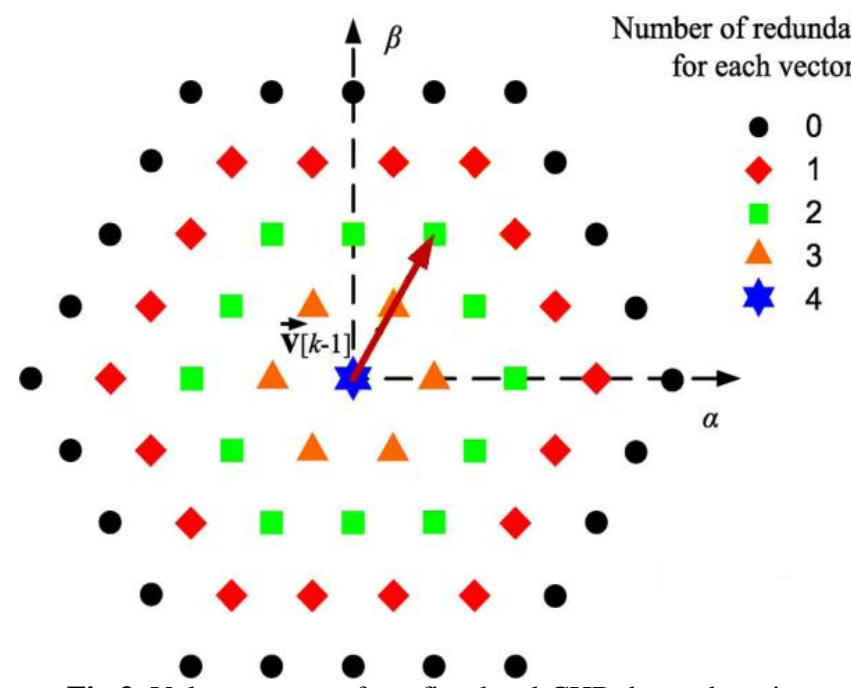

Fig.3. Voltage vectors for a five-level CHB three-phase inverter

The five-level inverter generates 125 voltage vectors, but with the vectorial transformation shown in (9), there are some redundant vectors generated with different voltage levels. With $C$ cells in each leg of the CHB inverter, the amount of non-redundant voltage vectors is

$V=12 C_{2}+6 C+1$

In Fig. 3, the voltage vectors and the number of equivalent voltage levels for a five-level CHB inverter, with 61 different voltage vectors, are shown. For the current control, only one voltage level state for each vector is necessary. The selection criterion is to select the voltage level states that minimize the common voltage vector, as defined in (7). This elimination of redundant vector does not affect the behavior of the current control, because the possible voltage vectors that can be applied to the load do not change. However, with this modification, the inverter voltage waveforms are improved, and the common-mode voltage is considerably reduced. Note that voltage vectors in the outer hexagon have no redundancies and some of them generate high common-mode voltage.

\section{Simulation Results}

The simulation of the model predictive current control of the CHB inverter with different sampling times is performed in the MATLAB/Simulink software. The simulation parameters are given in table 1 . The load used for simulation results is an $R L$ load. The input DC voltage, $\mathrm{V}_{\mathrm{DC}}=45 \mathrm{~V}$ is considered for each cell. Table.1. Simulation parameters

\begin{tabular}{|l|l|}
\hline Parameters & Values \\
\hline Input voltage (Vdc) & $45 \mathrm{~V}$ \\
\hline Load resistance (R) & $47 \Omega$ \\
\hline Load inductance (L) & $15 \mathrm{mH}$ \\
\hline Reference current & $0.95 \mathrm{~A}$ \\
\hline
\end{tabular}

The load current THD and the inverter voltage THD are observed for various values of the sampling times, and are given in table 2. The harmonic spectrum of load current waveform and the inverter voltage waveforms are analyzed using the Fast Fourier transform (FFT). Fig.4 shows the inverter phase to neutral voltage, load voltage and load current waveforms with a sampling time of $25 \mu \mathrm{s}$. The Fig.5 and Fig.6 shows the harmonic spectrum for load current and inverter voltage with a sampling time of $25 \mu \mathrm{s}$, respectively. Fig. 7 and Fig. 10 shows the inverter phase to neutral voltage, load voltage and load current waveforms with sampling times of $100 \mu \mathrm{s}$ and $200 \mu$ s, respectively. Fig.8 \& Fig.9 and Fig.11 \& Fig.12 shows the harmonic spectrum for load current and inverter voltage with sampling times of $100 \mu \mathrm{s}$ and $200 \mu \mathrm{s}$, respectively. 


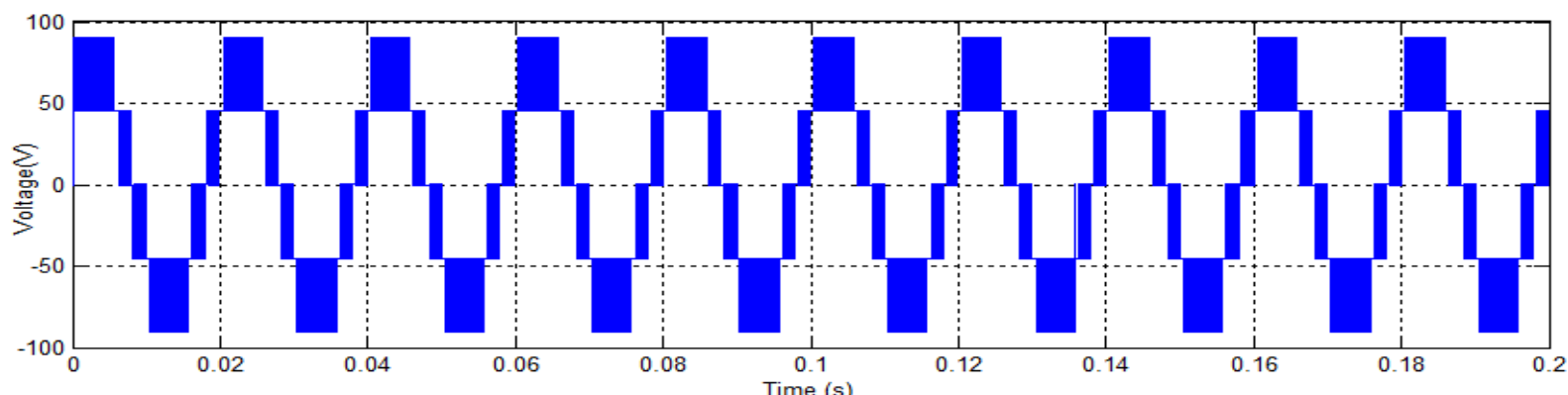

(a)

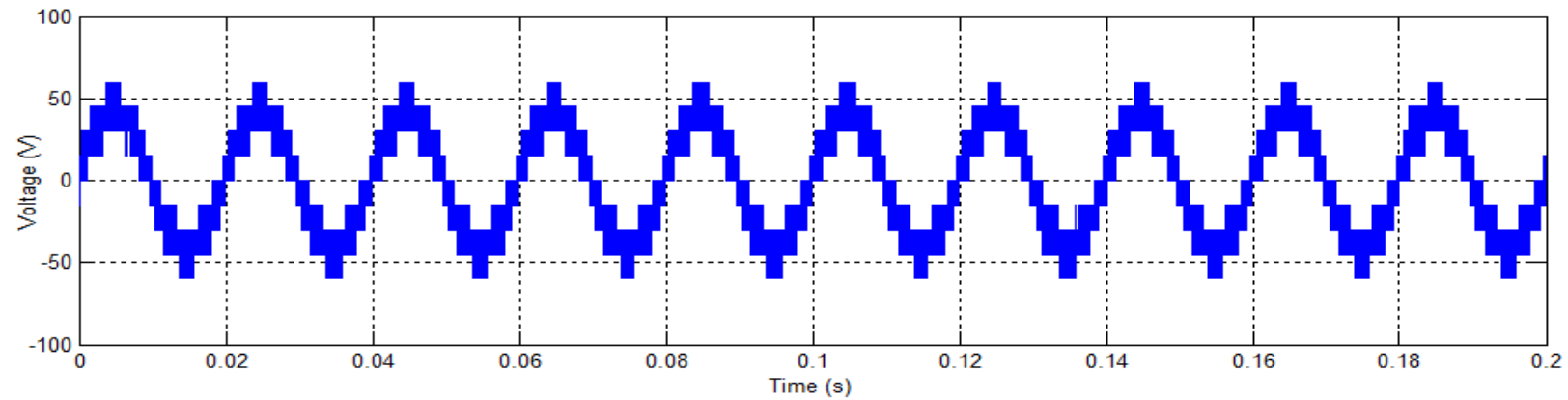

(b)

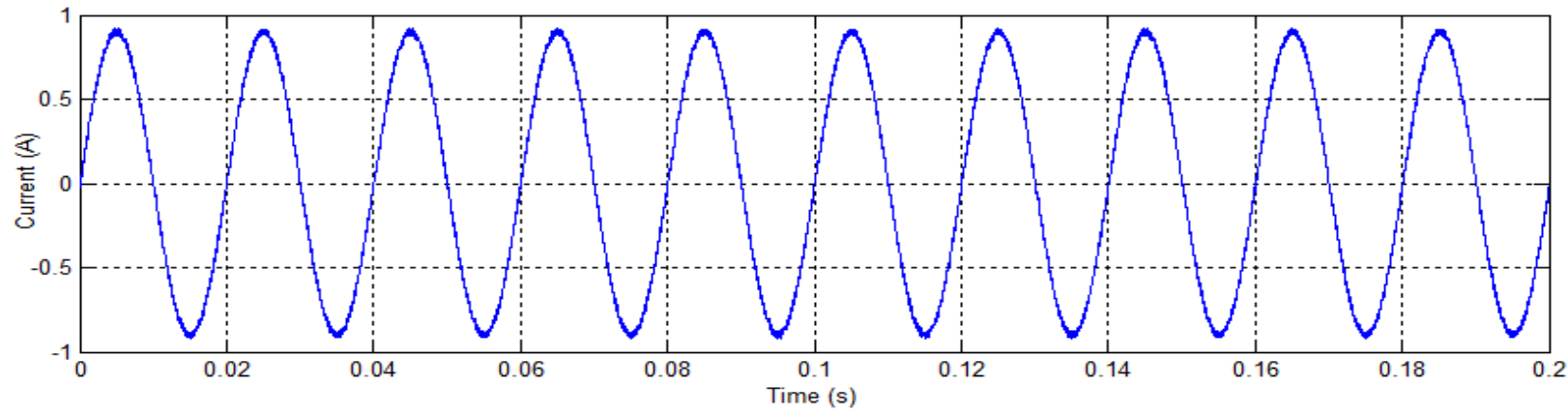

(c)

Fig.4. (a) Inverter Phase to Neutral Voltage, (b) Load Voltage and (c) Load Current Waveforms with sampling frequency of $25 \mu \mathrm{s}$

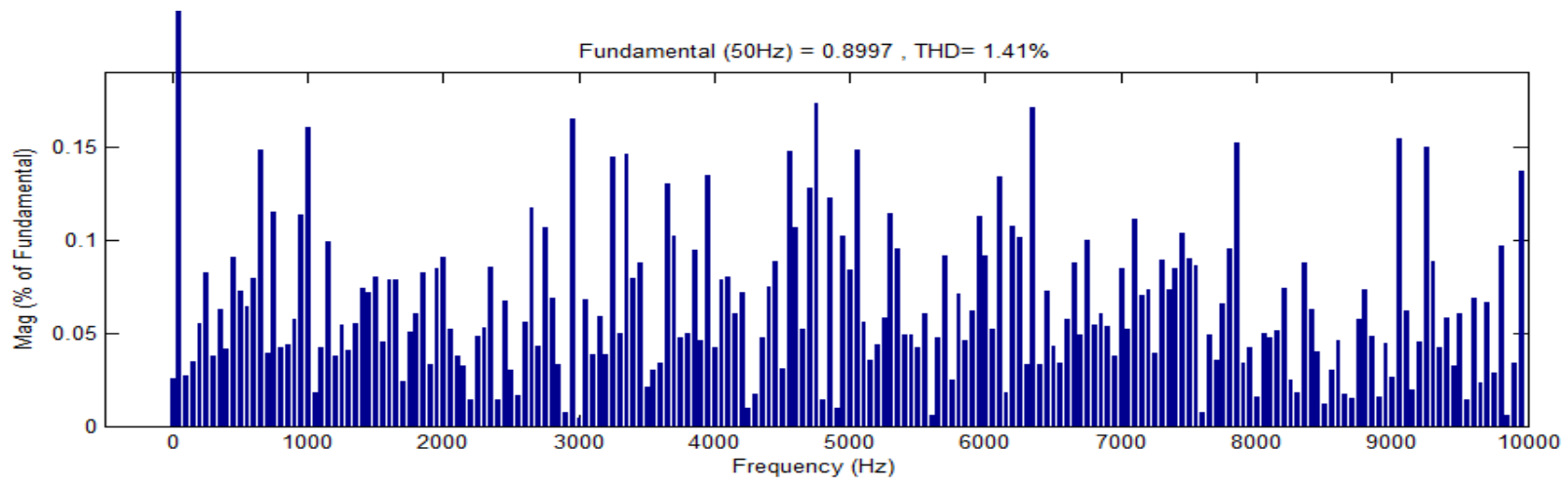

Fig.5. Harmonic spectrum for Load Current with a sampling time of $25 \mu \mathrm{s}$ 


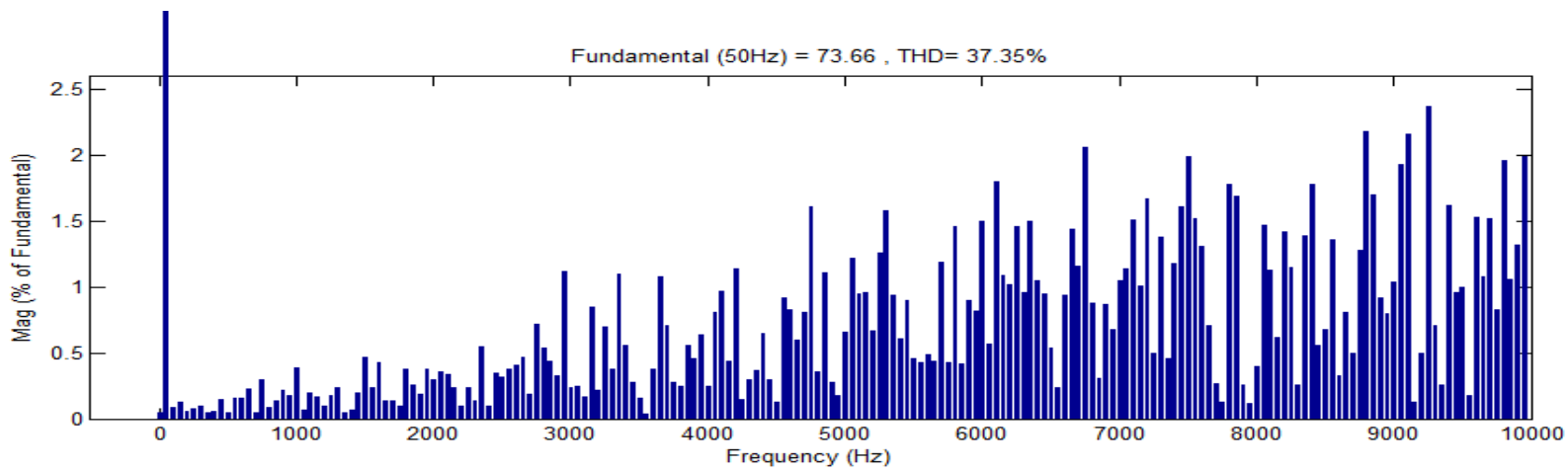

Fig.6. Harmonic spectrum for voltage with a sampling time of $25 \mu \mathrm{s}$

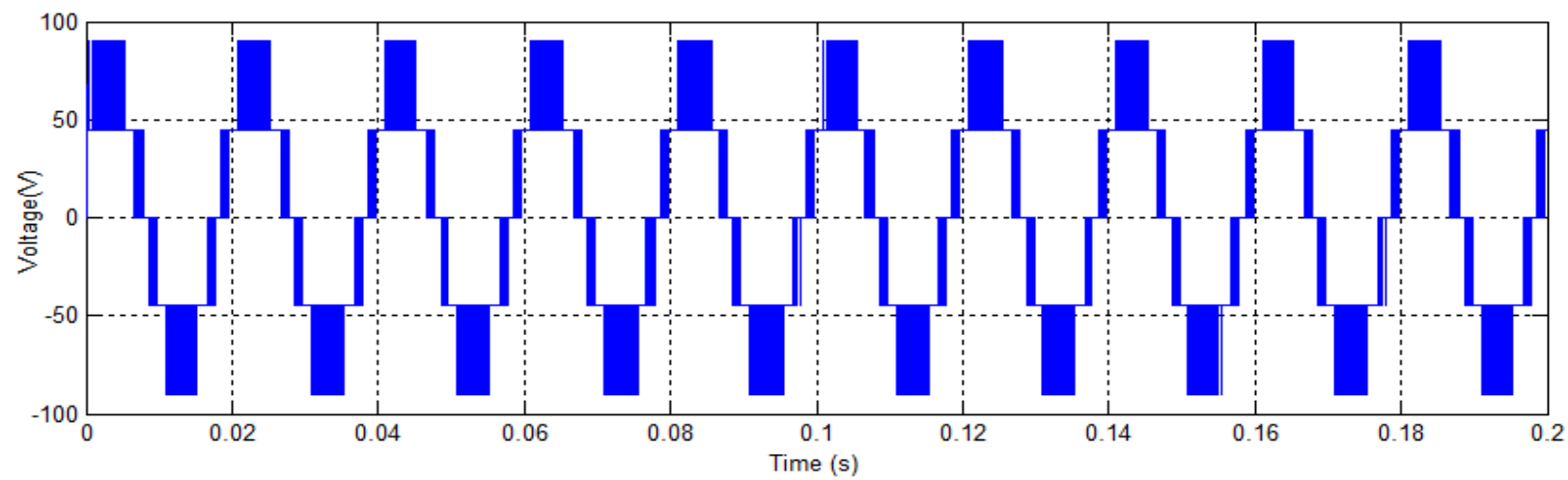

(a)

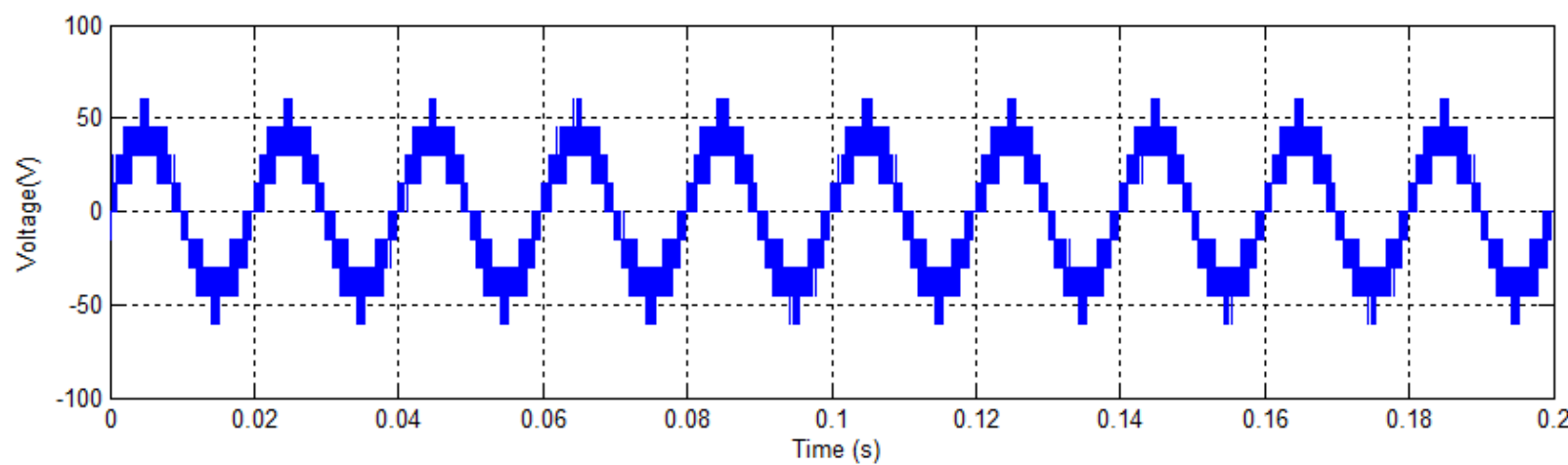

(b)

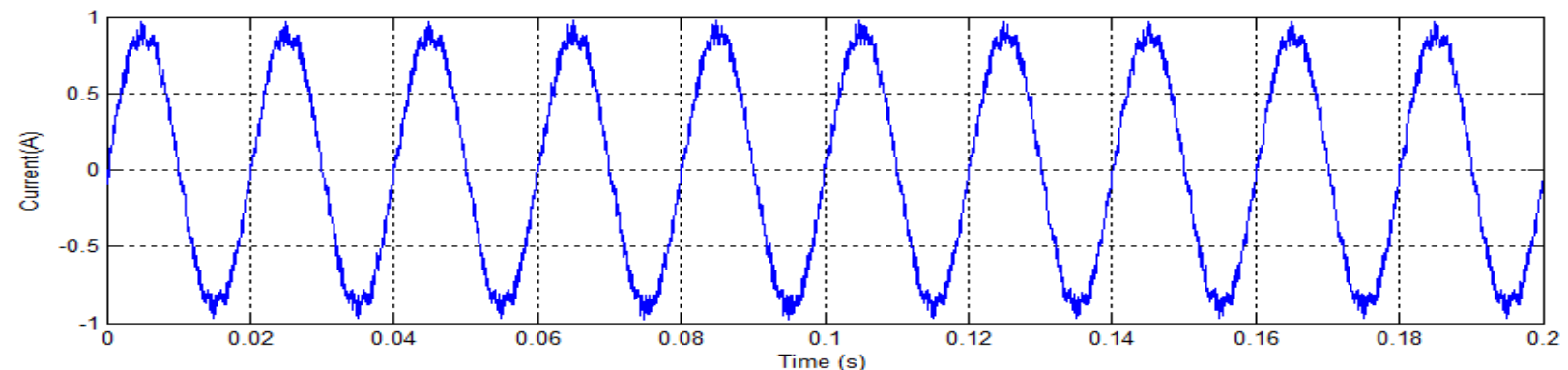

(c)

Fig.7. (a) Inverter Phase to Neutral Voltage, (b) Load Voltage and (c) Load Current Waveforms for Predictive controller with sampling frequency of $100 \mu \mathrm{s}$ 


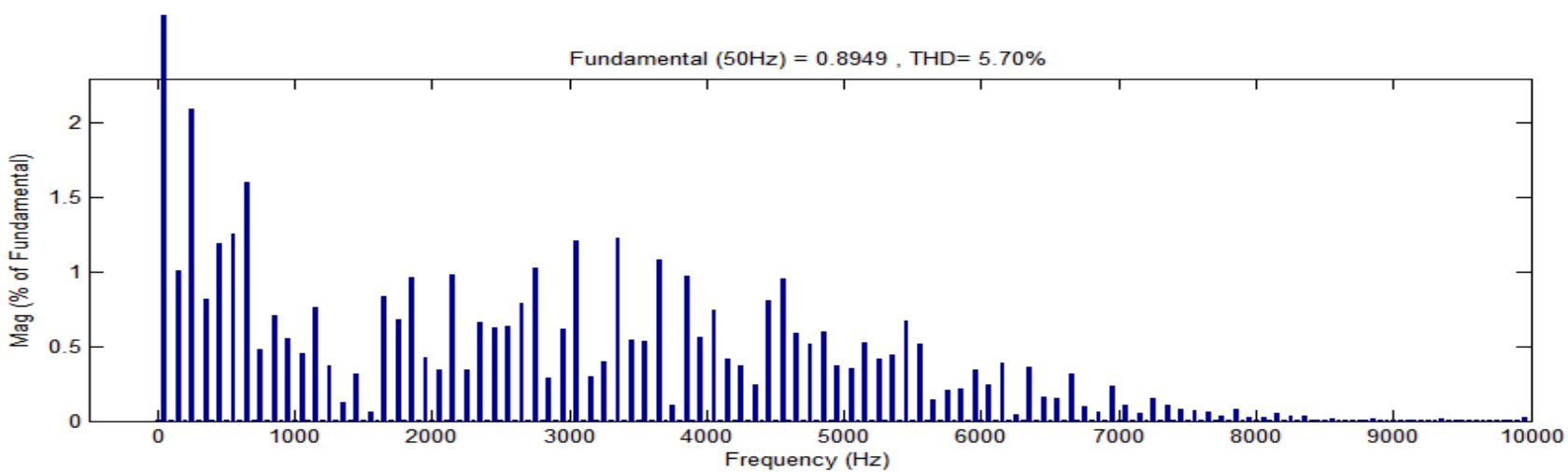

Fig.8. Harmonic spectrum for Load Current with a sampling time of $100 \mu \mathrm{s}$

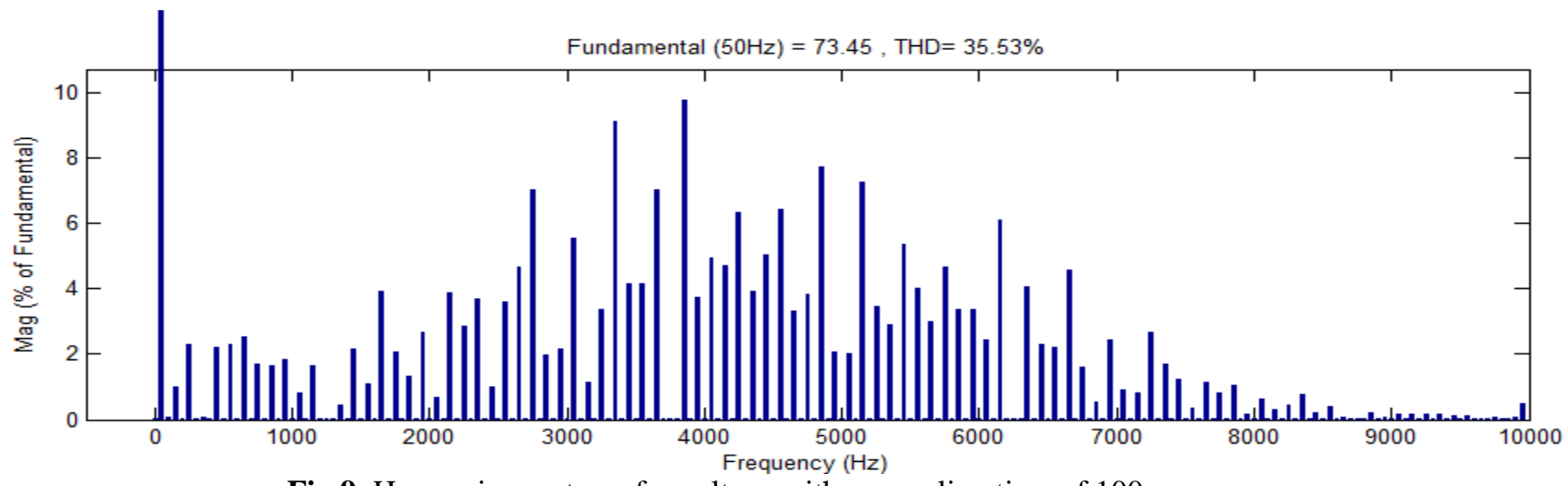

Fig.9. Harmonic spectrum for voltage with a sampling time of $100 \mu \mathrm{s}$

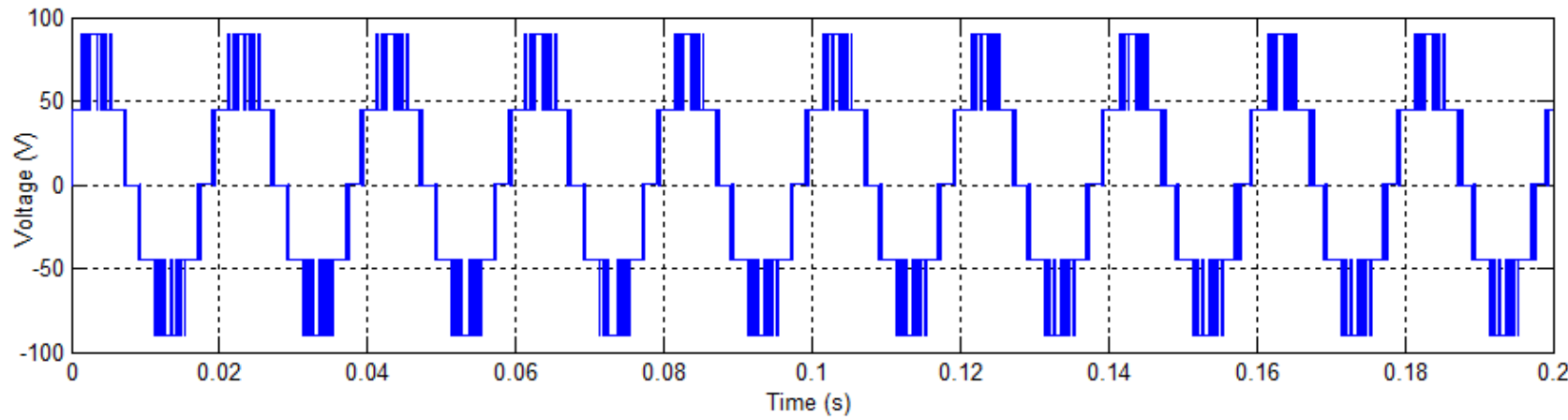

(a)

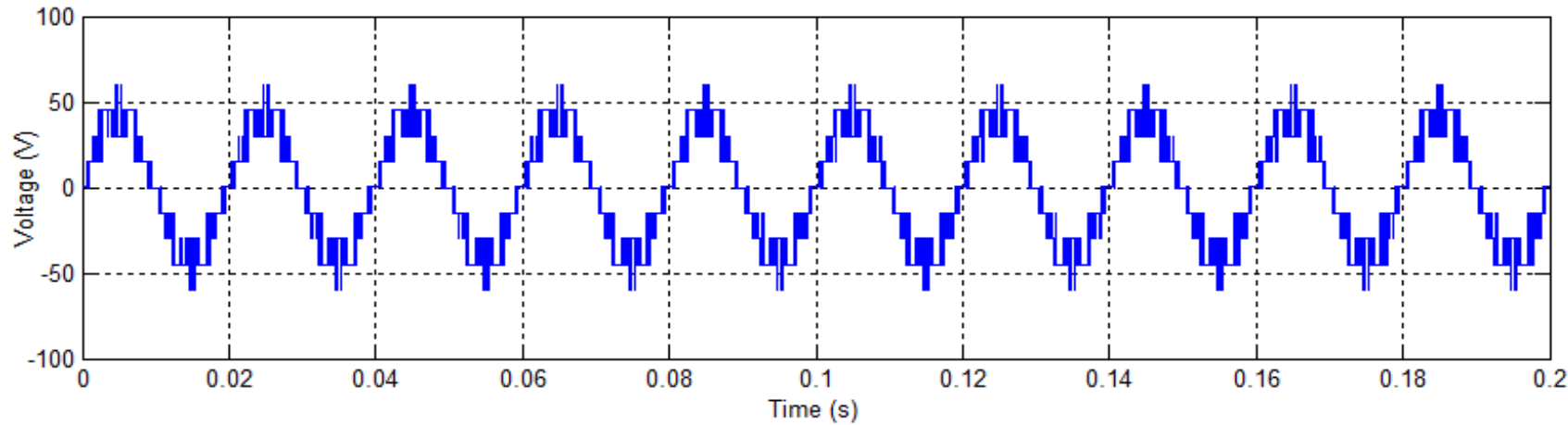

(b) 


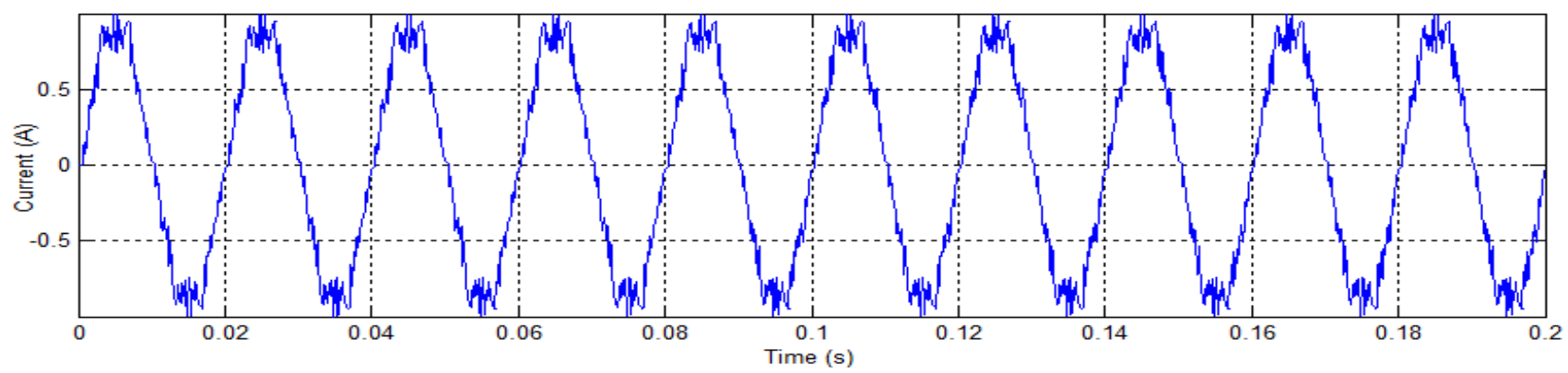

(c)

Fig.10. (a) Inverter Phase to Neutral Voltage, (b) Load Voltage and (c) Load Current Waveforms for Predictive controller with sampling frequency of $200 \mu \mathrm{s}$

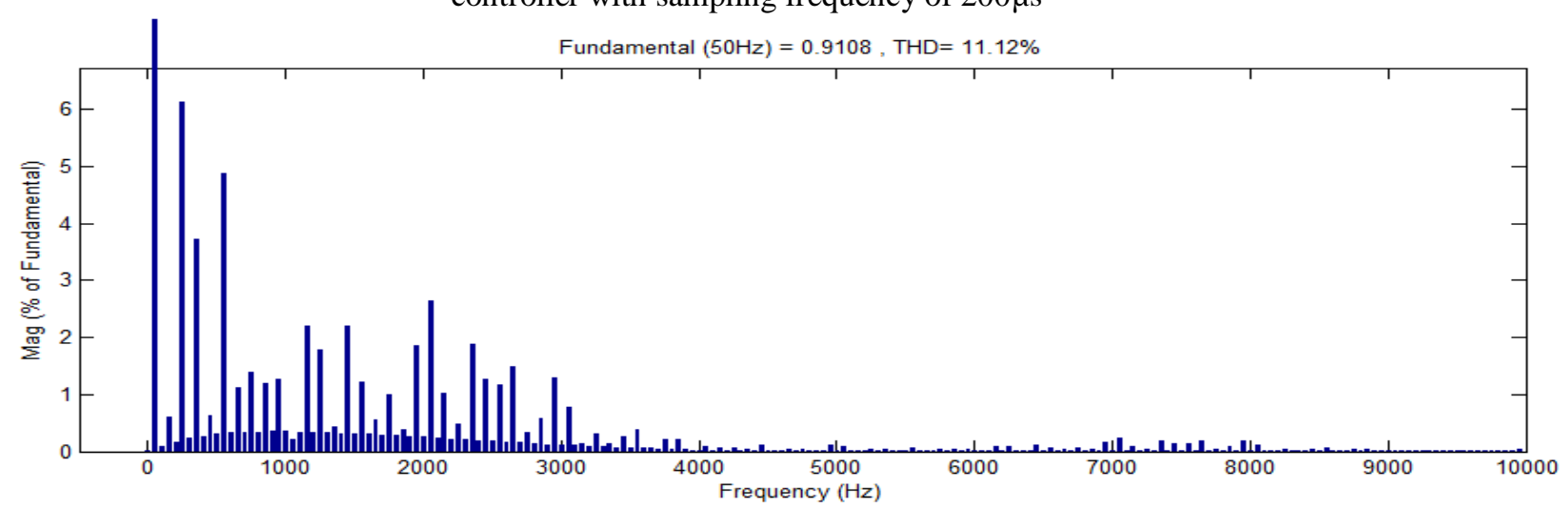

Fig.11. Harmonic spectrum for Load Current with a sampling time of $200 \mu \mathrm{s}$

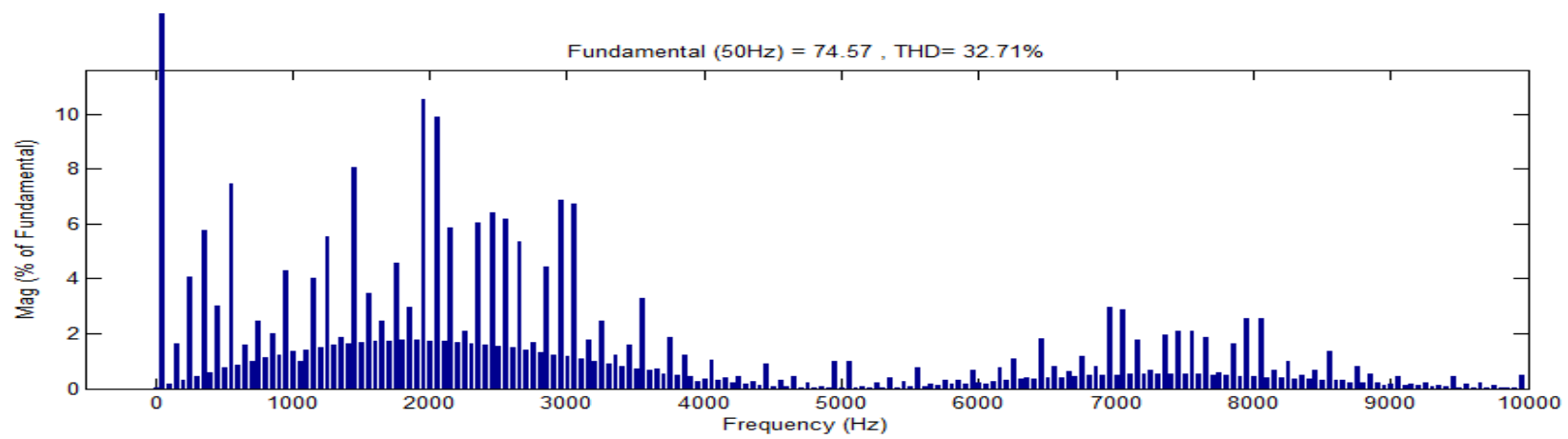

Fig.12. Harmonic spectrum for voltage with a sampling time of $200 \mu \mathrm{s}$

The sampling time has a significant impact on the ripple of the current and the switching frequency of the CHB inverter. From Table.2, it is observed that the current THD increases with increase in sampling time, and the voltage THD gradually decreases with increase in sampling time.

Table.2. Load Current THD and Inverter Voltage THD for different sampling times

\begin{tabular}{|c|c|c|}
\hline Sampling Times & Current THD & Voltage THD \\
\hline $25 \mu \mathrm{s}$ & $1.41 \%$ & $37.35 \%$ \\
\hline $50 \mu \mathrm{s}$ & $2.95 \%$ & $36.88 \%$ \\
\hline $75 \mu \mathrm{s}$ & $4.15 \%$ & $36.61 \%$ \\
\hline $100 \mu \mathrm{s}$ & $5.70 \%$ & $35.53 \%$ \\
\hline $125 \mu \mathrm{s}$ & $6.49 \%$ & $35.33 \%$ \\
\hline $150 \mu \mathrm{s}$ & $7.62 \%$ & $34.38 \%$ \\
\hline $175 \mu \mathrm{s}$ & $9.84 \%$ & $33.52 \%$ \\
\hline $200 \mu \mathrm{s}$ & $11.12 \%$ & $32.71 \%$ \\
\hline
\end{tabular}

The dynamic responses of the CHB inverter with the sampling times of $25 \mu \mathrm{s}, 100 \mu$ s and $200 \mu$ s for a step change in the amplitude of the reference current (from $1 \mathrm{~A}$ to $2 \mathrm{~A}$ at time 0.06s), are shown in the Fig.13-15, respectively. From the simulation results, it is observed that a major separation between the fundamental and 
switching harmonics is obtained by using a smaller sampling time. Also, the overall performance of the control is improved, achieving a very good reference tracking, and a better transient response.
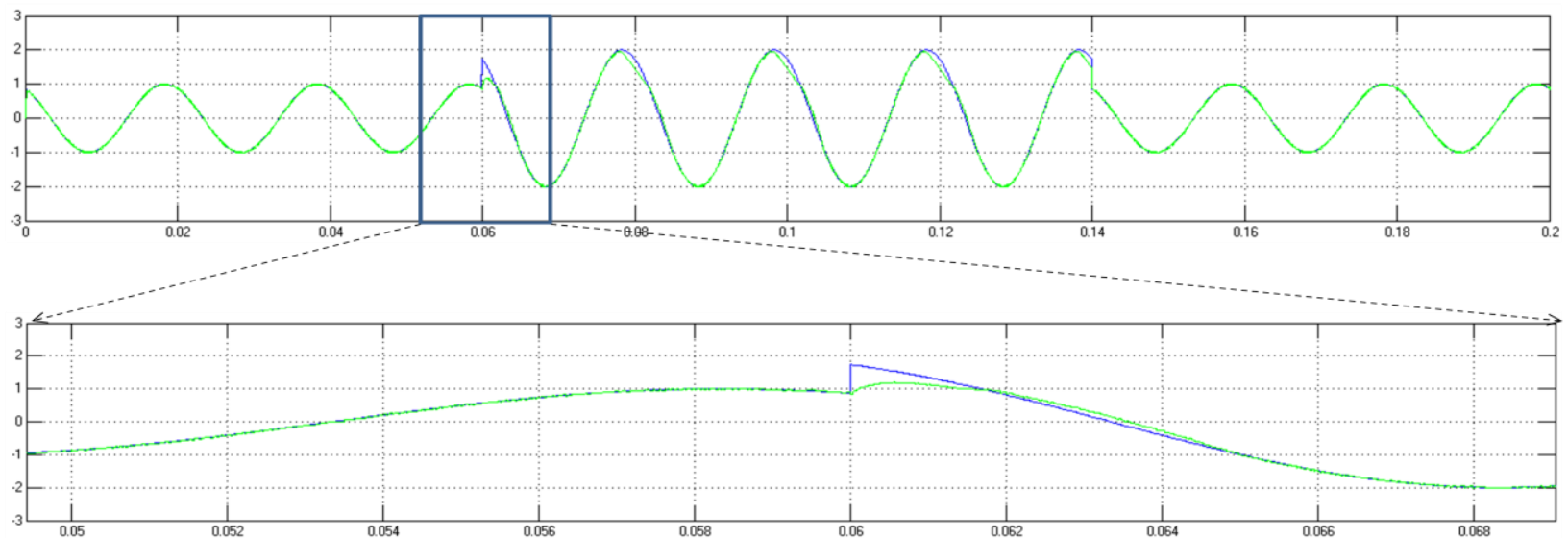

Fig.13. Reference Current Tracking for a sampling time of $25 \mu \mathrm{s}$
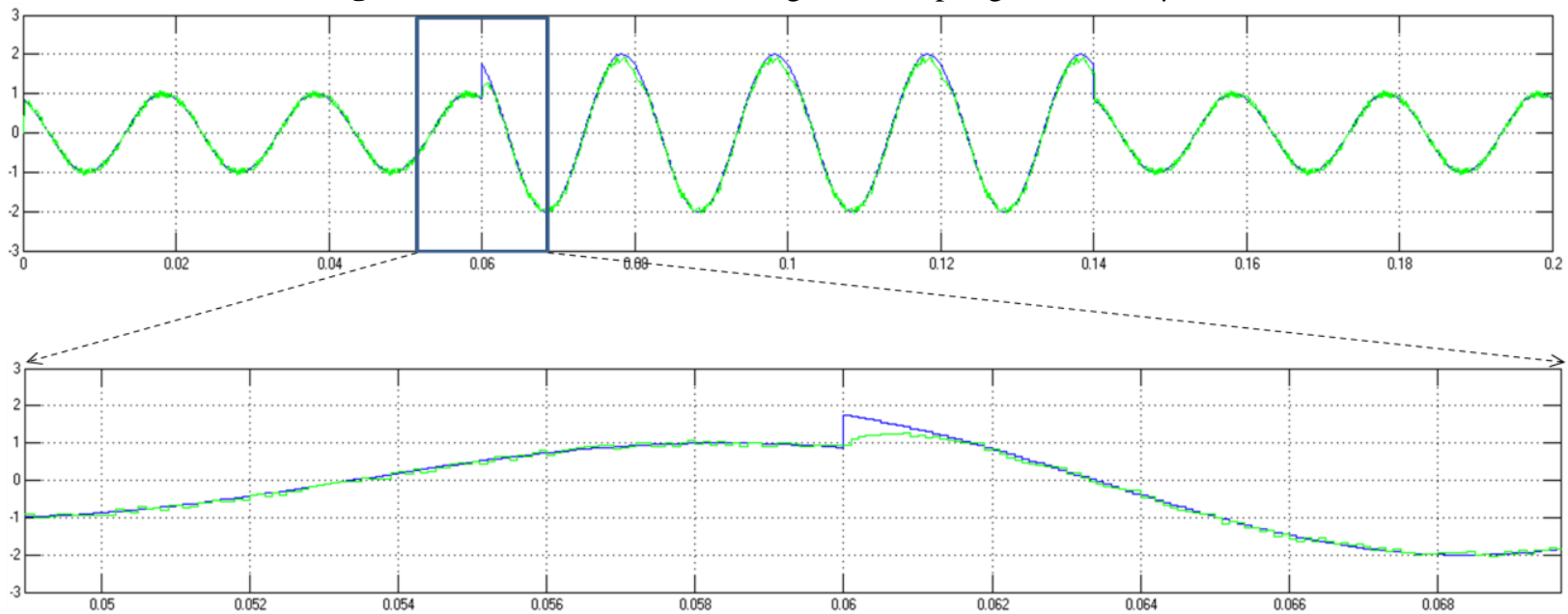

Fig.14. Reference Current Tracking for a sampling time of $100 \mu \mathrm{s}$
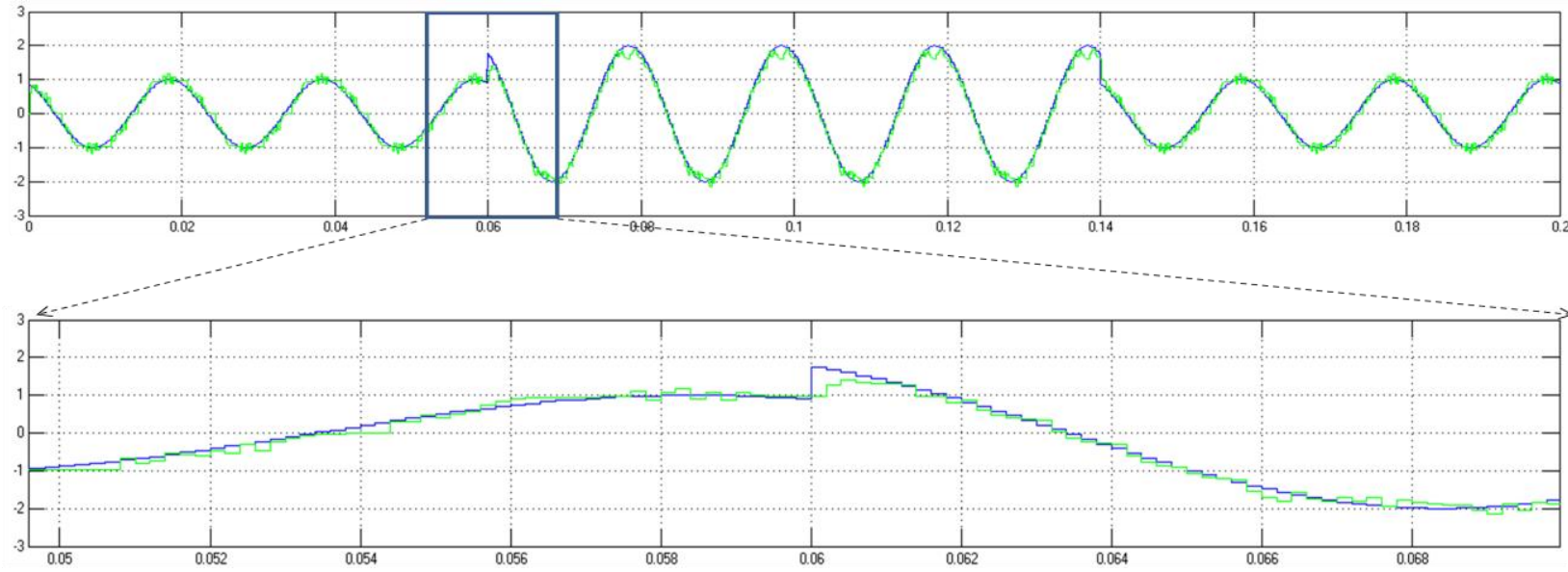

Fig.15. Reference Current Tracking for a sampling time of $200 \mu \mathrm{s}$

\section{Conclusion}

The model predictive current control of the CHB inverter with RL load is performed for different values of the sampling times. The model predictive current controller controls the load current very effectively and exhibits a very good reference tracking for smaller sampling time. The current and voltage harmonic spectrum for various sampling times are also observed. It is also observed that a major separation between the fundamental and switching harmonics is obtained by using a smaller sampling time, improving the overall performance of the model predictive current controller. 


\section{References:}

[1] J. Lai, and F. Peng, "Multilevel Converters - A New Breed of Power Converters". IEEE Trans. Ind. Appl., Vol. 32, No. 3, May/June, 1996

[2] C. Hochgraf, R. Lasseter, D. Divan, and T. A. Lipo, "Comparison of multilevel inverters for static var compensation," Proc. IEEE Ind.Applicat. Soc. Annu. Meeting, 1994, pp. 921-928.

[3] L. Tolbert, F. Z. Peng, and T. Habetler, "Multilevel converters for large electric drives," IEEE Trans. Ind. Electron., vol. 35, no. 1, pp. 36-44,Jan./Feb. 1999.

[4] H. Rudnick, J. Dixon, and L. Moran, "Delivering clean and pure power," IEEE Power Energy Mag., vol. 1, no. 5, pp. 32-40, Sep./Oct. 2003.

[5] J. Rodriguez, S. Bernet, B. Wu, J. O. Pontt, and S. Kouro, "Multilevel voltage-source-converter topologies for industrial mediumvoltage drives," IEEE Trans. Ind. Electron., vol. 54, no. 6, pp. 2930-2945,Dec.2007.

[6] J. Selvaraj, N. A. Rahim, "Multilevel Inverter For Grid-Connected PV System Employing Digital PI Controller," IEEE Trans. Ind. Electron.,vol. 56, no. 1, pp. 149-158, Jan 2009.

[7] B. Lin, and H. Lu, "New Multilevel Rectifier Based on Series Connection of H-Bridge Cell". IEE Proc. Electron. Power Appl., Vol.147, No. 4, July, 2000.

[8] J. Huang, and K.A. Corzine, "Extended operation of flying capacitor multilevel inverters". IEEE Trans. Power Electron., Volume 21, Issue1, Jan. 2006 Page(s): $140-147$.

[9] S. B. Monge, J. Rocabert, P. Rodriguez, S. Alepuz, J. Bordonau,"Multilevel Diode-Clamped Converter for Photovoltaic Generators With Independent Voltage Control of Each Solar Array," IEEE Trans. Ind. Electron., vol. 55, no. 7, pp. 2713-2723, July 2008.

[10] Y. Liu, F. L. Luo, "Trinary Hybrid 81-Level Multilevel Inverter for Motor Drive With Zero Common-Mode Voltage," IEEE Trans. Ind. Electron., vol. 55, no. 3, pp. 1014-1021, March 2008.

[11] J. I. Leon, S. Vazquez, A. J. Watson, L. G. Franquelo, P. W. Wheeler, J. M. Carrasco, "Feed-Forward Space Vector Modulation for Single-Phase Multilevel Cascaded Converters With Any DC Voltage Ratio,"IEEE Trans. Ind. Electron., vol. 56, no. 2, pp. 315-325, Feb 2009 .

[12] T.A. Meynard, and H. Foch, "Multi-level conversion: high voltage choppers and voltage-source inverters". Proc. IEEE Power Electronics Specialists Conference, 1992. PESC '92 Record., 23rd Annual IEEE.29 June-3 July 1992. Page(s):397 - 403 vol.1.

[13] P.W. Hammond, "A new approach to enhance power quality for medium voltage AC drives". IEEE Trans. Ind. Appl., Vol. 33, No.1,September/October 1981. January/February 1997.

[14] W. A. Hill and C. D. Harbourt, "Performance of Medium Voltage Multilevel Inverters", Proc. IEEE Ind. Appl. Society (IAS) Conference, Vol. 2, pp. 1186-1192, 1999.

[15] R. H. Osman, “A Medium Voltage Drive Utilizing Series-Cell Multilevel Topology for Outstanding Power Quality”, Proc. IEEE Ind. Appl. Society (IAS) Conference, pp. 2662-2669, 1999.

[16] J. D. Ainsworth, M. Davies, P. J. Fitz, K. E. Owen, and D. R. Trainer,"Static var compensator (STATCOM) based on single-phase chain circuit converters," Proc. Inst. Elect. Eng.-Gener. Transm. Distrib., vol. 145, July 1998, pp. 381-386.

[17] M. Marchesoni, M. Mazzucchelli, and S. Tenconi, "A non conventional power converter for plasma stabilization," in Proc. 19th IEEE Power Electron. Spec. Conf., Apr. 1988, vol. 1, pp. 122-129.

[18] B. P. McGrath and D. G. Holmes, "Multicarrier PWM strategies for multilevel inverters," IEEE Trans. Ind. Electron., vol. 49, no. 4, pp. 858-867, Aug. 2002.

[19] N. Celanovic and D. Boroyevich, "A fast space-vector modulation algorithm for multilevel three-phase converters," IEEE Trans. Ind. Appl., vol. 37, no. 2, pp. 637-641, Mar./Apr. 2001.

[20] J. I. Leon, S. Vazquez, A. J. Watson, L. G. Franquelo, P. W. Wheeler, and J. M. Carrasco, "Feed-forward space vector modulation for single-phase multilevel cascaded converters with any dc voltage ratio," IEEE Trans.Ind. Electron., vol. 56, no. 2, pp. 315-325, Feb. 2009 .

[21] J. Rodriguez, J. Pontt, P. Correa, P. Cortes, and C. Silva, "A new modulation method to reduce common-mode voltages in multilevel inverters,"IEEE Trans. Ind. Electron., vol. 51, no. 4, pp. 834-839, Aug. 2004.

[22] Y. Liu, H. Hong, and A. Huang, "Real-time calculation of switching angles minimizing THD for multilevel inverters with step modulation," IEEE Trans. Ind. Electron., vol. 56, no. 2, pp. 285-293, Feb. 2009

[23] Z. Du, L. M. Tolbert, J. N. Chiasson, and B. Ozpineci, "Reduced switching-frequency active harmonic elimination for multilevel converters," IEEE Trans. Ind. Electron., vol. 55, no. 4, pp. 1761-1770, Apr. 2008.

[24] J. Rodriguez, J. Pontt, C. A. Silva, P. Correa, P. Lezana, P. Cortes, and U. Ammann, "Predictive current control of a voltage source inverter," IEEE Trans. Ind. Electron., vol. 54, no. 1, pp. 495-503, Feb. 2007.

[25] P. Cortes, J. Rodriguez, D.E.Quevedo, and C. Silva, "Predictive current control strategy with imposed load current spectrum," IEEE Trans. Power Electron., vol. 23, no. 2, pp. 612-618, Mar. 2008.

[26] P. Cortes, M. P. Kazmierkowski, R. M. Kennel, D. E. Quevedo, and J. Rodriguez, "Predictive control in power electronics and drives," IEEE Trans. Ind. Electron., vol. 55, no. 12, pp. 4312-4324, Dec. 2008.

[27] S. Kouro, P. Cortes, R. Vargas, U. Ammann, and J. Rodriguez, "Model predictive control—A simple and powerful method to control power converters," IEEE Trans. Ind. Electron., vol. 56, no. 6, pp. 1826-1838, Jun. 2009.

[28] J. Rodriguez, J. Pontt, C. A. Silva, P. Correa, P. Lezana, P. Cortes, and U. Ammann, "Predictive current control of a voltage source inverter," IEEE Trans. Ind. Electron., vol. 54, no. 1, pp. 495-503, Feb. 2007.

[29] J. Rodriguez, J. Pontt, C. Silva, M. Salgado, S. Rees, U. Ammann, P. Lezana, R. Huerta, and P. Cortés, "Predictive control of a three-phase inverter," Electron. Lett., vol. 40, no. 9, pp. 561-562, Apr. 29, 2004.

[30] S. Muller, U. Ammann, and S. Rees, "New time-discrete modulation scheme for matrix converters," IEEE Trans. Ind. Electron., vol. 52, no. 6, pp. 1607-1615, Dec. 2005.

[31] P. Cortes, J. Rodriguez, P. Antoniewicz, and M. Kazmierkowski, "Direct power control of an AFE using predictive control," IEEE Trans. Power Electron., vol. 23, no. 5, pp. 2516-2523, Sep. 2008

[32] J. Rodriguez, J. Pontt, C. Silva, P. Cortés, S. Rees, and U. Ammann, "Predictive direct torque control of an induction machine," in Proc. EPEPEMC, Riga, Latvia, Sep. 2-4, 2004.

[33] H. Miranda, P. Cortes, J. I. Yuz, and J. Rodriguez, "Predictive torque control of induction machines based on state-space models," IEEE Trans. Ind. Electron., vol. 56, no. 6, pp. 1916-1924, Jun. 2009.

[34] T. Geyer, G. Papafotiou, and M. Morari, "Model predictive direct torque control—Part I: Concept, algorithm, and analysis," IEEE Trans. Ind. Electron., vol. 56, no. 6, pp. 1894-1905, Jun. 2009.

[35] G. Papafotiou, J. Kley, K. G. Papadopoulos, P. Bohren, and M. Morari, "Model predictive direct torque control-Part II: Implementation and experimental evaluation," IEEE Trans. Ind. Electron., vol. 56, no. 6, pp. 1906-1915, Jun. 2009. 
[36] R. Vargas, P. Cortes, U. Ammann, J. Rodriguez, and J. Pontt, "Predictive control of a three-phase neutral-point-clamped inverter," IEEE Trans. Ind. Electron., vol. 54, no. 5, pp. 2697-2705, Oct. 2007.

[37] P. Lezana, R. Aguilera, and D. E. Quevedo, "Model predictive control of an asymmetric flying capacitor converter," IEEE Trans. Ind. Electron., vol. 56, no. 6, pp. 1839-1846, Jun. 2009.

[38] M. A. Perez, P. Cortes, and J. Rodriguez, "Predictive control algorithm technique for multilevel asymmetric cascaded H-bridge inverters," IEEE Trans. Ind. Electron., vol. 55, no. 12, pp. 4354-4361, Dec. 2008.

[39] S. Kouro, B. La Rocca, P. Cortes, S. Alepuz, B. Wu, and J. Rodriguez, "Predictive control based selective harmonic elimination with low switching frequency for multilevel converters," in Proc. IEEE Energy Conv.Congr. Expo., Sep. 2009, pp. 3130-3136.

[40] K. Sivakumar, Anandarup Das, Rijil Ramchand, Chintan Patel and K. Gopakumar, "A Hybrid Multilevel Inverter Topology for an Open-End Winding Induction-Motor Drive Using Two-Level Inverters in Series with a Capacitor-Fed H-Bridge Cell," IEEE Trans. on Industrial Electronics, Vol. 57, No. 11, November 2010. 